\title{
Baby Milk*
}

\section{By AlBReCht HofHeINZ}

On September 2, the hashtag \#laban_al-'askūr explodes on social media [ $\nearrow$ Social Media]. It is tempting to translate this as \#cop_milk to reflect the wordplay, in Arabic, on laban al'asfiūr 'crop milk', an Egyptian expression denoting the unimaginable and impossible. Birds are not mammals, after all. Most people are surprised to learn that 'bird's milk' (the literal rendering of laban al-'asfür) really does exist-both al-Ahrām and Wikipedia attest to this unheard-of natural phenomenon. And ordinary citizens are just as stunned to learn of the 'arMY milk' (another attempt to translate laban al-'askūr) that the Egyptian military is ready to provide in order to defuse citizens' anger when subsidized infant formula suddenly turns all but out of reach for average Egyptian families. The army has 30 million cans of toddler milk stored in their barracks? Why? What for? Apparently, the nation's foremost institution really does want to make sure it can steer its subjects from the cradle to the grave. And "20 years from now," one of the first tweets predicts, they will yell at you, "you dare insult the army that taught you and suckled you? \#Badr_International_School \#laban_al-'askūr." This tweet combines reference to the toddler milk affair with a stab at the school the military established a year ago to attract well-paying youngsters (20,000 EGP for a kindergarten place) away from private international schools, and to provide them "the weapons of education necessary for their future endeavors." Badr School is facing a backlash as it embarks on its second year, with people objecting to the military's engagement in yet another socioeconomic sector. While critical voices question both the motives and the ability of the military to manage what should be civilian affairs, others take less issue with that. "The military is running all of Egypt, why would I be concerned about it running a school?" says a mother of two kids there. Many do believe that the products and services the military delivers really are better than what others have to offer. Yet this belief becomes the object of derision as well. "They say that Badr School is whiter than white," Abla Fāhītā, the wildly popular Egyptian muppet character, tweets on August 29. Why? "They constantly sweep the floor there with the General" detergent. Can anyone object to using General ("Max Clean, Max Fresh") to secure, as the commercial promises, an "Ultimate clean house"? $[\lambda$ Inferiority $=$ Superiority (Satire) $]$. It is not easy to ascertain who at any one moment has the upper hand in this war of words. For many - teachers and parents at Badr School, drivers filling gas at the Wataniyya patriotic petrol stations, consumers buying fruit and eggs, noodles and refrigerators produced in military-owned farms and factories, the sick placing their hopes on drugs and medical equipment imported by the military, and for countless others - the military represents a force serving the nation rather than individual private interests. Protests against the military's role are therefore often regarded as being the result of a conspiracy directed from abroad, and thus Badr's school principal reveals in an interview with MadaMasr that:

* Re-published (with minor modifications, mainly in the cross-references) from JAIS 17 (2017): 466-69.

Journal of Arabic and Islamic Studies • 21 (2021) - Themed Section In2016: *31-*34 (C) Albrecht Hofheinz, Dept. of Culture Studies and Oriental Languages (IKOS), Univ. of Oslo, NO 
There's a fortune teller in America whose prophecies all come true. He predicted that in one of the Arab countries there will be a president who pretends to represent Islam, though he is far from it [a reference to deposed president Mursī] and that the president who comes next would unite the Arab region and destroy the American economy. That president will have a name made up of two repeated syllables [he

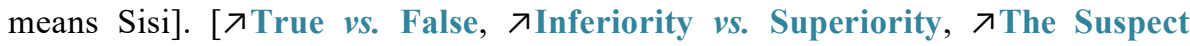
Foreigner]

It is in such a climate that the baby milk crisis erupts. When women on August 31 suddenly and without prior warning find they no longer can buy infant formula at the subsidized price of 5-17 EGP but are being referred to the open market where the cost of a can quickly rises to 60-70 EGP, they are shocked and pour their anger into street demonstrations attracting media attention. The women and their families find themselves confronted with a fait accompli as no one has prepared them for the Health Ministry's decree tightening the criteria for being able to obtain subsidized milk [ $\nearrow$ Valentine's Day (EG), $\nearrow^{66}$ The System" $v S_{0}$ "The People"]. The Ministry, for its part, is merely trying to help "stem the subsidy haemorrhage," to contribute to the overall fiscal consolidation that the IMF requires to approve its biggest ever Middle East loan (12bn USD over 3 years, 4 times as much as Sisi's predecessors dared to ask for) [ $\nearrow$ Dollar Crisis]. This grander order of things is lost, however, on countless women who complain that they now no longer know how to feed their babies [ $\lambda$ Affluence vs. Destitution]. At this point, the army is there to save them. To counter what it describes as "monopolistic practices by pharmaceutical companies" (and without mentioning that the main company involved is the state-owned Egyptian Pharmaceutical Trading), the Armed Forces promise to deliver 30 million cans of baby milk - half of Egypt's annual demand - to be sold at pharmacies for "no more than 30 EGP" [ 7 The Voice from Above]. A few observers point out that this is twice the expense incurred for importing the milk, meaning a net profit of 450 million EGP "for a tiny crisis created in just one day" (coincidentally, this corresponds exactly to the amount, c. 51 million USD, that the Ministry of Health claims it uses per year for supplying infant formula) [ 7 Tricking the System / Tricked by the System]. But such nit-picking cannot deter the authorities. Soon, fleets of trucks bearing the message "Don't pay more than 30 pounds!" appear on streets and newspaper pages, and "France Lait" cans labelled "Long live Egypt... with regards, The Armed Forces" hit the shelves. A pernickety tweep notes that these army-branded milk canisters bear a production date going back a month before the outbreak of the shortage [ $\lambda$ True vs. False], but further speculations on who created the emergency are drowned by social media outrage at another scandalous aspect of the issue. For the Ministry of Health follows the army in the attempt to defuse the crisis, softening its decree to give access to the subsidized substitute not only in cases where the mother is completely unable to breastfeed, but also where she does not produce enough mother's milk of her own. To prevent abuse of the system, women now have to undergo a breast examination before being handed out the subsidized formula. While the banned Muslim Brotherhood tries to exploit the issue in their broadcasts from abroad, claiming that the regime is forcing women to undergo breast examinations in public - a claim strongly denied by the authorities - other commentators draw parallels to the army's earlier practice of carrying out 'virginity tests' on female demonstrators. As if to confirm that a patriarchal mindset dominated by a view of woman primarily as reproductive sexual bodies

jaig • 21 (2021) - Themed Section In2016: *31-*34 
that need to be contained and controlled, still runs deep, a member of parliament publicly declares, the same day the baby milk affair breaks, his opposition to a legislative amendment harshening the punishment for performing female genital mutilation. Egypt's "men suffer from sexual weakness," he explains. "For the sake of equality between men and women, women should therefore be circumcised to reduce their sexual desire." [ $\nearrow$ Male vs. Female]

Such an 'extreme' formulation is no longer a matter of consensus in Egypt (even though it can still frequently be encountered on social media); neither is the same parliamentarian's call to introduce virginity tests for girls wanting to enter university. Nevertheless: sexual harassment and gendered violence remain rampant and constitute an important framework for how women are treated and have to comport themselves. Just how important is indicated by the way the affair is framed when it becomes a buzz issue on social media, to the extent that it is picked up by the Arabic HuffPost under the headline "Medical Examination of the Mothers of Egypt on the Street." Criticism of the political economy of things is drowned out by moral outrage; and this moral outrage is less about the state subjecting its citizens' bodies to humiliation, but over the allegedly public breast examinations, i.e. the public exposure of women's bodies that are supposed to remain hidden from view [ $\lambda$ Normality $v$ s. Heroism]. Small wonder that the 'shame' of breastfeeding in public is one of the main reasons for why $60 \%$ of Egyptian women rely on infant formula in the first place.

\section{Related Entries}

ARRAYS - Dollar Crisis $\downarrow$ Social Media $\downarrow$ The Suspect Foreigner $\downarrow$ The Voice from Above $\downarrow$ Tricking the System / Tricked by the System

CODES - Affluence vs. Destitution Male vs. Female Inferiority vs. Superiority Normality vs. Heroism "The System" vs. "The People" t True vs. False

CODES COLLAPSED - Inferiority $=$ Superiority (Satire)

\section{References}

ABLA FAHITA (@AblaFahita). "Biyqūlūlī Madāris Badr International School dī naḍīa fulla... 'alà țūl biyimsahū 'l-arḍ bi'l-Generāl,” Twitter, August 29, 2016, <https://twitter.com/AblaFahita/ status/770262197469638656>.

“About BIS." Badr International Schools, 2016, <http://www.bis-eg.com/About\%20BIS.aspx?id=2>, accessed November 13, 2017.

'AF̄̄̄Ī, Hiba. "“Madā Maṣr' fī ziyāra maydāniyya li-madrasat al-quwwāt al-musallaḥa al-duwaliyya."

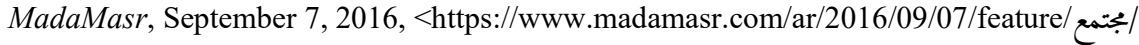

مدى -مصر-في-زيارة-ميدانية-لمدرسة-القوا.

Ahmed ANwAR (@A7mdAnwar).“*Ba'd 20 sana* [...].” Twitter, Sep. 1, 2016, 7:53 p.m., $<$ https://twitter.com/A7mdAnwar/status/771405683422031872>.

Dāliyā 'UthmĀN. "al-Ğaysh yatasallam awwal shahnna min albān al-ațâl: «mā tidfa'sh aktar min 30 Ğinēh» (șuwar)." al-Maṣrī al-Yōm, September 19, 2016, <http://www.almasryalyoum.com/news/ details/1011013>.

“Egyptian MP Referred to Ethics Committee for Supporting FGM Due to 'Sexually Weak Men'." Egyptian Streets, September 9, 2016, <https://egyptianstreets.com/2016/09/09/egyptian-mpreferred-to-ethics-committee-for-supporting-fgm-due-to-sexually-weak-men/>.

jais 21 (2021) - Themed Section In2016:*31-*34 
"Faḥs țịbbī li-ummahāt Miṣr fî 'l-shāric... khulūw al-thady min al-laban sharṭ șarf hạaīb al-ațâal almuda"am." Huffington Post 'Arabī, September 8, 2016, <http://www.huffpostarabi.com/2016/09/ 08/story_n_11904302.html>.

FetEHA, Ahmed and Andrew MAYEDA. "IMF Approves Biggest-Ever Mideast Loan to Revive Egypt's Economy." Bloomberg, November 11, 2016, <https://www.bloomberg.com/news/ articles/ 201611-11/imf-approves-biggest-ever-mideast-loan-to-revive-egypt-s-economy>.

Ghāda IBRĀHĪM. "Afụal munạ̣ḍif lil-sērāmīk.” al-Mirsāl, April 5, 2015, <https://www.almrsal.com/ post/225523>.

El-GizAwI, M. (@MElGizawi). “Fākrīn azmit \#laban_al-aṭ̂āl wi'l-ẓuhūr il-sarīi li \#laban_al-'askūr?! [...]." Twitter, September 23, 2016, 4:12 p.m., <https://twitter.com/MElGizawi/status/779322 $505282588672>$.

“Got Milk? Egypt to Check Women's Breasts Before Supplying Baby Formula.” Middle East Eye, September 7, 2016, <http://www.middleeasteye.net/news/got-milk-egypt-wants-check-women-sbreasts-supplying-baby-formula-1819401048>.

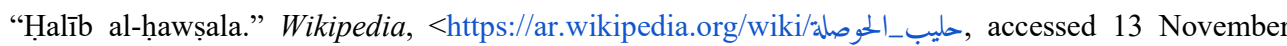
2017>.

Huwayda “ABD AL-HAMīD. “«Laban al-'așfūr»” ḥaqīqa am khayāl?!” al-Ahrām al-Zirāc̄e 6 April 2016, $<$ http://agri.ahram.org.eg/News/22948.aspx.

"Ilhāmī 'Ağīna yuțālib bi-kashf țibbī li-ithbāt 'udhriyyat al-banāt ka-sharṭ lil-qubūl bi'l-ǧāmicāt." alYawm al-Sābic, September 29, 2016, <http://www.youm7.com/story/2016/9/29/2902061/

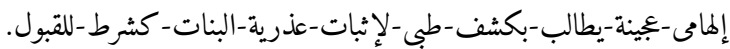

MoghAzI, Amr (@AmrMoghazi5).“\#Laban_al-'askūr wașal [...].” Twitter, September 21, 2016, $<$ https://twitter.com/AmrMoghazy5/status/778520809790930944>.

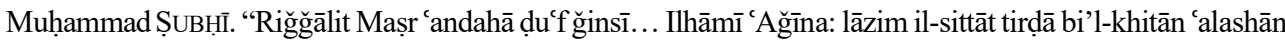
il-ağala timshī.” Barlamānī, September 1, 2016, <http://parlmany.youm7.com/News/5/ 119212/ رجالة-مصر-عندها-ضعف-جنسى-إلهامى-جينة-لازم-الستات-ترضى.

“Need Baby Milk? You'll Need a Breast Exam First, Says Egyptian Health Ministry.” Middle East Eye, September 12, 2016, <http://www.middleeasteye.net/in-depth/features/need-baby-milk-show-usyour-breasts-says-egyptian-health-ministry-subsidised-women-military-986760374>.

Qanāt al-Sharq. "Haytham Abū Khalīl ba'da kārithat al-kashf 'alà thady al-ummahāt ka-shart li-șarf laban al-aṭ̂āl...āh yā nakhkhāsīn yā ḥuthālā!....” YouTube, Sep. 5, 2016, <https://youtu.be/ 8IPB3COIPo>.

al-SA'DANĪ, Rabīi . "Haqīqat faḥ̣ «athdā̄ al-ummahāt» fī Marākiz al-Usra... wa'l-Șiḥ̣a: sharṭ lil-ḥuṣūl 'alà 'l-albān.” al-Tahrīr, September 9, 2016, <http://www.tahrirnews.com/Posts/printing/485346/ألبان

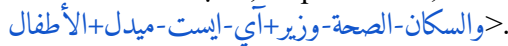

al-Sharika al-Mișriyya li-Tiğārat al-Adwiya, updated June 30, 2016, <http://www.eptc-egydrug. com>, accessed November 13, 2017.

al-Thawra Tağma'unā. "Infōgrāf \| Laban al-'askūr." YouTube, September 5, 2016, <https:// youtu.be/F16PYK3dhiI>.

\albrecht.hofheinz@ikos.uio.no

jaig • 21 (2021) - Themed Section In2016: *31-*34 